\title{
Multistage Horizontal Subsurface Flow vs. Hybrid Constructed Wetlands for the Treatment of Raw Urban Wastewater
}

\author{
José Alberto Herrera-Melián ${ }^{1, * \mathbb{C}}$, Mónica Mendoza-Aguiar ${ }^{2}$, Rayco Guedes-Alonso ${ }^{1}{ }^{1}$, \\ Pilar García-Jiménez ${ }^{3}{ }^{-}$, Marina Carrasco-Acosta ${ }^{3}$ and Ezio Ranieri ${ }^{4}$ \\ 1 Department of Chemistry, Institute of Environmental Studies and Natural Resources (i-UNAT), \\ University of Las Palmas de Gran Canaria, 35017 Las Palmas, Spain; rayco.guedes@ulpgc.es \\ 2 School of Civil and Industrial Engineering, University of Las Palmas de Gran Canaria, \\ 35017 Las Palmas, Spain; monica.mendoza101@alu.ulpgc.es \\ 3 Department of Biology, Institute of Environmental Studies and Natural Resources (i-UNAT), \\ University of Las Palmas de Gran Canaria, 35017 Las Palmas, Spain; pilar.garcia@ulpgc.es (P.G.-J.); \\ marina.carrasco@ulpgc.es (M.C.-A.) \\ 4 Department of Biology, University of Bari, 70125 Bari, Italy; ezio.ranieri@uniba.it \\ * Correspondence: josealberto.herrera@ulpgc.es
}

Received: 1 May 2020; Accepted: 19 June 2020; Published: 23 June 2020

\begin{abstract}
In this study, pilot-scale hybrid constructed wetlands (CWs) and multistage horizontal subsurface flow CWs (HF CWs) have been studied and compared for the treatment of raw urban wastewater. In the hybrid CWs, the first stage was a mulch-based horizontal subsurface flow CW and the second stage was a vertical subsurface flow CW (VF CW). The VF CWs were used to determine if sand could improve the performance of the hybrid $\mathrm{CW}$ with respect to the mulch. In the multistage HFs, mulch, gravel and sand were used as substrates. The effect of water height (HF10: $10 \mathrm{~cm}$ vs. HF40: $40 \mathrm{~cm}$ ) and surface loading rate (SLR: 12 vs. $24 \mathrm{~g}$ Chemical Oxygen Demand (COD) $/ \mathrm{m}^{2} \mathrm{~d}$ ) has been studied. The results show that the use of sand in the vertical flow stage of the hybrid CW did not improve the average performance. Additionally, the sand became clogged, while the mulch did not. The effect of water height on average pollutant removal was not determined but HF10 performed better regarding compliance with legal regulations. With a SLR of $12 \mathrm{~g} \mathrm{COD} / \mathrm{m}^{2} \mathrm{~d}$, removals of HF10 were: $79 \%$ for $\mathrm{COD}, 75 \%$ for $\mathrm{NH}_{4}{ }^{+}-\mathrm{N}, 53 \%$ for dissolved molybdate-reactive phosphate-P (DRP), $99 \%$ for turbidity and $99.998 \%$ for E. coli and total coliforms. When SLR was doubled, removals decreased for $\mathrm{NH}_{4}{ }^{+}-\mathrm{N}: 49 \%$, DRP: $-20 \%$, E coli and total coliforms: $99.5-99.9 \%$, but not for COD $(85 \%)$ and turbidity (99\%). Considering the obtained results and the simplicity of the construction and operation of HFs, HF10 would be the most suitable choice for the treatment of raw urban wastewater without clogging problems.
\end{abstract}

Keywords: wastewater; shallow constructed wetland; horizontal flow; substrate; organic mulch; gravel; sand

\section{Introduction}

Constructed wetlands (CWs) are natural, low-cost reactors, particularly adequate for wastewater treatment and reuse in small communities. Molinos-Senante et al. [1] collected the opinions of 29 international experts from the academic, research and industrial fields about the most suitable wastewater treatment technology for small communities. CWs (24\%) and ponds (23\%) were the most preferred alternatives, while extended aeration and membrane bioreactors were the least preferred ones. Considering the water flow, CWs can be classified as horizontal flow or vertical flow and surface flow or 
subsurface flow CWs. Horizontal subsurface flow CWs (HF CWs) are easily designed and constructed. Additionally, their operation and maintenance is simple and inexpensive. However, their efficacy regarding nitrification and total $\mathrm{N}$ removal is usually low. Consequently, vertical subsurface flow $\mathrm{CWs}$ (VF CWs) and hybrid CWs (combinations of HF CWs and VF CWs) have been successfully tested [2]. Nevertheless, two important drawbacks of VF CWs when compared with HF CWs are achieving a homogeneous distribution of the influent over the bed, and the higher clogging risk because of the finer substrate material used.

The porous media is a basic CW component since it supports biofilm and plants. Gravel and sand are the conventional components of porous media, but these materials are being extracted faster from the environment than they can be replaced. Sand and gravel are the most extracted group of materials worldwide, exceeding both fossil fuels and biomass [3]. The environmental impact of sand extraction includes coastal and river erosion, coral reef degradation, biodiversity loss and the spread of invasive species. These environmental impacts have a profound effect on the local human population in terms of seawater intrusion in coastal aquifers, thus affecting domestic water supply and increasing salinization of cultivated land, the increase in potential breeding sites for malaria-transmitting mosquitoes, etc. All these effects can result in social and political conflicts [4], particularly in developing countries [5]. Thus, more sustainable materials for CW beds should be found.

In recent decades, many different alternative materials such as industrial wastes and agricultural and forest byproducts have been tested in an attempt to improve $\mathrm{CW}$ performance and/or environmental sustainability [6,7]. Organic substrates obtained from agro-forest wastes can be more environmentally friendly than gravel and sand since local material would be used and the impacts of mining and transport would be minimized. In this regard, Wang et al. [8] obtained good results with an organic substrate composed of peat/crushed pine bark. Additionally, rice husk and organic mulch have been successfully employed in the removal of total nitrogen [9-11]. Moreover, organic substrates can increase the removal of micro-pollutants by sorption $[12,13]$. Denitrifying bioreactors are a particular case of organic-based CWS that have been used to reduce the nitrate concentration of different effluents. The carbon-rich media promotes nitrate reduction to $\mathrm{N}_{2}$ gas under anaerobic conditions. However, recent studies have shown their long term performance regarding the removal of fecal indicators [14].

The typical substrate depth of subsurface flow CWs is $0.5 \mathrm{~m}$, but several authors have found that shallow constructed wetlands (SCWs) can improve the removal of nitrogen, organic matter $[15,16]$ and estrogenic disruptors by a more efficient dissolved oxygen transfer to the media [17]. Additionally, a SCWs require fewer building materials, and consequently a lower cost of construction, operation and maintenance [18]. Holland et al. [19] studied the effect of wetland depth and flow rate on residence time distribution (RTD) characteristics. They used two different average depth settings: $16.6 \mathrm{~cm}$ for low water level and $39.8 \mathrm{~cm}$ for high water level. The obtained results indicated that flow rates did not have a significant effect on RTD characteristics, but all the parameters indicating hydraulic efficiency exhibited lower efficiency for the higher water levels.

In the literature, there are studies on the comparison of horizontal and hybrid CWs, but few consider the use of agro-forest residues as substrates of CWs, and particularly the possibility of substituting gravel and sand by agro-forest wastes in VF CWs. In our opinion, using locally abundant and available wastes as CW substrates can greatly improve their economic and environmental sustainability. Thus, the main goal of this work was to compare a multistage HF CW with hybrid CWs for the treatment of raw wastewater without clogging. Thus, the hybrid CWs were used to test the effect of the age of the mulch-based substrate in the HF stage and to compare sand with mulch substrates for VF CWs. With the multistage HF CWs, the effects of water height, surface loading rate (SLR), and hydraulic loading rate (HLR) were studied.

\section{Experimental}

The pilot-scale CWs were constructed in September 2015. Monitoring started in November 2015 and ended in July 2016. The CWs were located outdoors and the influent was wastewater from the 
Campus of Tafira of the University of Las Palmas de Gran Canaria (Canary Islands, Spain). The inflow was collected in a $17-\mathrm{m}^{3}$ pit and controlled with a timer-controlled triturating pump located at the bottom of the pit. The pump was programmed to work for 3 min every $2 \mathrm{~h}$ during the whole day, seven days a week, during all the experimental period. No sampling was performed during rainy days and during the university vacation periods of Christmas, summer and Easter. Figure 1 illustrates the CWs employed. The multistage HF CWs and the HF stage of the hybrid CW were built with plastic recipients, each with a volume of $265 \mathrm{~L}$, a height of $50 \mathrm{~cm}$, width of $55 \mathrm{~cm}$, length of $125 \mathrm{~cm}$, and a surface area of $0.7 \mathrm{~m}^{2}$. As can be seen in Figure 1, four treatment lines were designed to study:

- The effect of water depth and SLR on the multistage HF CWs. For this, two lines composed of four recipients each were built. The first two units had a mulch substrate, the third one had gravel and the last one had sand. The plastic recipients were perforated at the bottom to be connected in series with plastic tubes of $5 \mathrm{~cm}$ in diameter. The holes were covered with a $0.02-\mathrm{m}$ gravel layer to avoid the clogging of the tubes by the mulch. The purpose of this substrate sequence (mulch-gravel-sand) was to minimize the clogging of the porous media, which is usually stronger near the inlet [20]. Additionally, the first unit was located above the other ones to favor the aerobic degradation of the retained solids and to minimize clogging and ponding [21]. The palm mulch allows for significant loads of Total Suspended Solids (TSS) and Chemical Oxygen Demand (COD), without clogging [22]. The mulch was obtained by trituration of dry branches of the Canarian palm tree (Phoenix canariensis) which is very abundant in the zone. The mulch had a porosity of $54 \%$ and a hygroscopicity of about $10 \%$. The gravel was basaltic with $49 \%$ porosity and average diameter of $6.5 \mathrm{~mm}$. The last unit of the HF was built with sand (45.5\% carbonate, porosity: $42 \%$, average diameter: $0.32 \mathrm{~mm}$ ) in an attempt to provide a final polishing of the water, for the improved removal of pathogens [23], and to reduce the water flow speed. These lines were used to determine the efficiency of a HF in which gravel has been partially replaced by mulch, as well as the effect of water height. Thus, a line was built with a water height of about $10 \mathrm{~cm}$ (HF10), as well as a second line with a $40 \mathrm{~cm}$ height (HF40). The CWs were planted with Phragmites, Cyperus and Canna, with the exception of the final sand-based units that were not unplanted. In addition to the influent and effluent, an intermediate sampling point was included in the HF CW systems to determine the contribution of the first (HF40-1, HF10-1) and second stages (HF40-2, HF10-2) of the removals.

- The hybrid CWs were built with an organic-based HF CW followed by a VF CW. The HF stage had mulch and the VF stages were plastic cylindrical recipients with a surface area of $0.1 \mathrm{~m}^{2}$ and depth of $70 \mathrm{~cm}$. The hybrid CWs were used to: (i) compare them with the multistage HF CW, and (ii) compare sand with mulch in the vertical flow stage. A 10-cm-high layer of gravel was used at the bottom of the VF stages to avoid the outlet clogging. The effluents of the HF stages were directed by gravity to the VF stages. The hybrid CWs were not planted in order to minimize the number of variables to be considered.

\subsection{Water Analysis}

All the parameters were analyzed according to standard methods [24] in un-filtered samples. $\mathrm{N}$ and $\mathrm{P}$ species have been determined photometrically with a Zuzi Uv-vis spectrophotometer 4201/50 (Auxilab, Spain). Total N (TN) and P (TP) were determined after alkaline peroxydisulfate digestion at $120^{\circ} \mathrm{C}$ for $90 \mathrm{~min}$. After digestion, TN was determined as nitrites and TP as molybdate-reactive phosphates. Dissolved molybdate-reactive phosphate-P(DRP) was measured directly without digestion. Nitrite ions were measured photometrically after the formation of a pink diazo dye with sulfanilamide and N N-(1-naphthyl)-ethylene-diamine. Nitrate ions were analyzed as nitrites after reduction with hydrazine-Cu-Zn solution. E. coli and total coliforms were enumerated with membrane filtration and cultivation at $37^{\circ} \mathrm{C}$ for $24 \mathrm{~h}$ with a selective chromogenic agar (Panreac, Spain). Chemical Oxygen Demand (COD) was determined by open reflux digestion with dichromate and titration and a ferrous standard. Biochemical Oxygen Demand $\left(\mathrm{BOD}_{5}\right)$ was measured with the manometric 
method with nitrification inhibition (Velp, Italy). TSS was determined gravimetrically. Turbidity was determined with a portable nephelometer (Velp, Italy). Sulfate ions were determined nephelometrically after precipitation with $\mathrm{BaCl}_{2}$. Ammonium-N $\left(\mathrm{NH}_{4}{ }^{+}-\mathrm{N}\right)$ was determined with a selective electrode (Metrohm, Switzerland). COD, turbidity, $\mathrm{NH}_{4}{ }^{+}-\mathrm{N}, \mathrm{DRP}$, E. coli and total coliforms have been routinely measured to determine the effect of the selected design parameters.
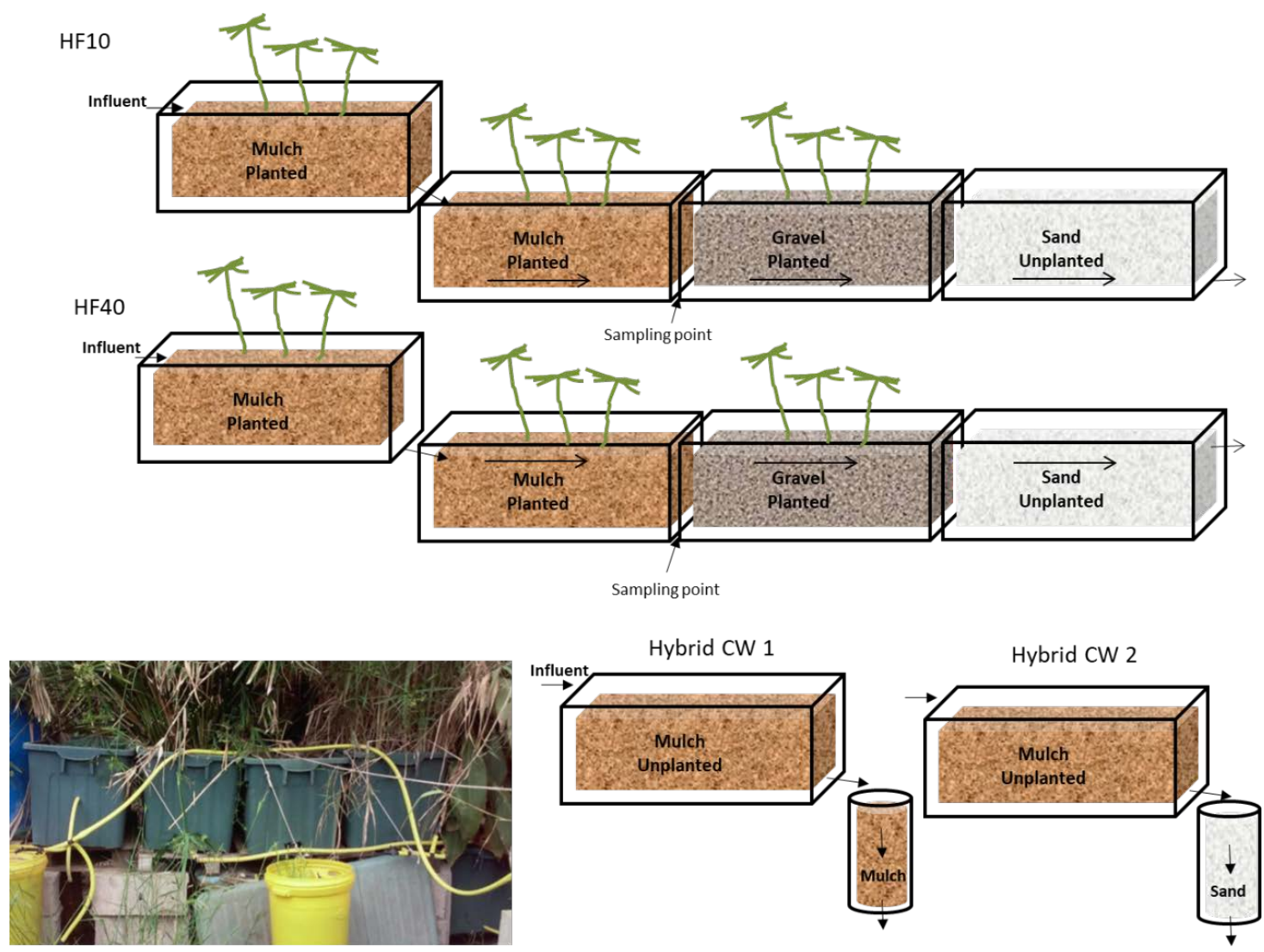

Figure 1. Scheme of the constructed wetland $(\mathrm{CW})$ mesocosms employed in the study: multistage horizontal subsurface flow CWs (HF CWs) with water heights of $10 \mathrm{~cm}$ (HF10) and $40 \mathrm{~cm}$ (HF40); hybrid CWs with mulch-based HF CW followed by vertical subsurface flow (VF) with mulch (Hybrid CW 1) and sand (Hybrid CW 2). The photograph shows the hybrid CWs and the first unit of the multistage HF CWs.

\subsection{Statistics}

Removals, surface loading rates and removal rates have been determined according to the following expressions:

- Removal: $100 \times\left(C_{\text {inf }}-C_{\text {eff }}\right) / C_{\text {eff }}$

- SLR: $C_{\text {inf }} \times Q \times 10^{-3} / S$

- Removal rate: $\left(C_{\text {inf }}-C_{\text {eff }}\right) \times Q \times 10^{-3} / S$

where $C_{\text {inf: }}$ concentration $(\mathrm{mg} / \mathrm{L})$ in the influent; $C_{\text {eff: }}$ concentration $(\mathrm{mg} / \mathrm{L})$ in the effluent; $Q$ : inflow $(\mathrm{L} / \mathrm{d}), \mathrm{S}$ : surface area of the reactor $\left(\mathrm{m}^{2}\right)$.

A simple ANOVA test was used for statistical analysis to determine significant statistical differences in the performance of wastewater treatments. The analyses were carried out with the R-Commander program from the free R software package. When data were not homoscedastic (Bartlett test) or normally distributed (Shapiro-Wilks test), the non-parametric Kruskal-Wallis test was employed. A significance level of $p=0.05$ was used. 


\section{Results and Discussion}

\subsection{Characteristics of the Influent and Surface Loading Rates}

The influent can be considered as medium strength [25] for almost all the parameters, with the exception of TN and $\mathrm{NH}_{4}{ }^{+}-\mathrm{N}$, which were closer to high strength (Table 1). As expected, the concentrations of $\mathrm{NO}_{\mathrm{x}}{ }^{-}$(nitrates + nitrites) in the influent were always lower than $1 \mathrm{ppm}$, being undetectable in most samples. The average concentration of $\mathrm{TN}(70 \mathrm{mg} / \mathrm{L})$ was dominated by that of $\mathrm{NH}_{4}{ }^{+}-\mathrm{N}(57 \mathrm{mg} / \mathrm{L})$. The high $\mathrm{NH}_{4}{ }^{+}-\mathrm{N} / \mathrm{TN}$ ratio ( $81 \%$ ) may be due to the particular characteristics of the campus, in which the urine proportion in wastewater can be higher than those of other $\mathrm{N}$ sources. Similar concentrations and $\mathrm{NH}_{4}{ }^{+}-\mathrm{N} / \mathrm{TN}$ ratio were found for a schoolhouse in Estonia [26].

Table 1. Average concentrations ( \pm standard deviation) and number of data of the measured parameter. The units are $\mathrm{mg} / \mathrm{L}$ except turbidity (NTU) and pathogen indicators (CFU/100 mL).

\begin{tabular}{cc}
\hline & Average \pm Std. Dev., Number of Data \\
\hline COD & $497 \pm 197,32$ \\
\hline BOD & $259 \pm 57,13$ \\
\hline TSS & $170 \pm 121,14$ \\
\hline Turbidity & $180 \pm 105,23$ \\
\hline pH & $7.5 \pm 0.22,14$ \\
\hline Sulfate $^{+}$NH $_{4}{ }^{-N}$ & $62 \pm 37,10$ \\
\hline $\left.\mathrm{NO}_{2}{ }^{-}+\mathrm{NO}_{3}{ }^{-}\right)-\mathrm{N}$ & $57 \pm 20,37$ \\
\hline $\mathrm{TN}$ & $0.4 \pm 0.82,24$ \\
\hline $\mathrm{DRP}$ & $70 \pm 22,11$ \\
\hline $\mathrm{TP}$ & $7.4 \pm 3.4,25$ \\
\hline E. coli & $10 \pm 4,12$ \\
\hline Total coliforms $^{2}$ & $5.4 \pm 8.2\left(\times 10^{6}\right), 16$ \\
\hline
\end{tabular}

Similarly, the average concentration of DRP was about $74 \%$ of that of TP.

The HF CWs and the hybrid CWs were fed with $144 \mathrm{~L} / \mathrm{d}$ and $44 \mathrm{~L} / \mathrm{d}$, respectively, of raw wastewater from the campus. Table 2 shows the average SLRs for the multistage HF CWs and hybrid CWs. The surface loadings of this study (HLR: $41-54 \mathrm{~L} / \mathrm{m}^{2} \mathrm{~d}$ and COD-LR: $20-25 \mathrm{~g} / \mathrm{m}^{2} \mathrm{~d}$, Table 2) were not statistically different enough to be able to compare their removals and were above those reported by other authors. For example, Vymazal found an average value of $13.9 \mathrm{~g} \mathrm{COD} / \mathrm{m}^{2} \mathrm{~d}$ in the Czech Republic, where the unsatisfactory removal of $\mathrm{NH}_{4}{ }^{+}-\mathrm{N}$ or $\mathrm{P}$ was achieved [2].

Table 2. Average surface loading rate (SLR) ( \pm standard deviation) of the HF CWs and the hybrid CWs.

\begin{tabular}{ccc}
\hline & HF CWs & Hybrid CWs \\
\hline HLR, L/m $\mathrm{m}^{2} \mathrm{~d}$ & $41 \pm 14$ & HF: $61 \pm 14$, VF: $426 \pm 102$, HF-VF: $54 \pm 13$ \\
COD-LR, g/m $\mathrm{m}^{2} \mathrm{~d}$ & $20 \pm 11$ & HF: $30 \pm 14$, VF: $60 \pm 49$, HF-VF: $25 \pm 11$ \\
TSS-LR, g/m $\mathrm{m}^{2} \mathrm{~d}$ & $6 \pm 3$ & HF: $10 \pm 6$, VF: $6 \pm 4$, HF-VF: $9 \pm 5$ \\
\hline
\end{tabular}

\subsection{Multistage HF CWs}

\subsubsection{Effect of the Water Level Height}

The conventional depth of HF CWs is 50-60 cm. However, different authors have observed that shallow HFs ( $<27 \mathrm{~cm}$ deep) achieved better removals of $\mathrm{COD}, \mathrm{BOD}_{5}, \mathrm{NH}_{4}{ }^{+}-\mathrm{N}$ and DRP. The better 
performance of shallower HF CWs could be explained by considering that: (i) water can be forced to go through the rooting zone of the plants, and (ii) shallower substrates displayed higher redox potential and slightly higher dissolved oxygen concentrations $[15,27]$. Thus, the effect of water height was considered a key parameter in this study. According to the results for the entire experimental period (Table 3), HF10 was, in general, more efficient than HF40, and was significantly better for turbidity.

Table 3. Average removal (\%) ( \pm standard deviation) of HF40 and HF10 for entire experimental period.

\begin{tabular}{ccc}
\hline & HF40 & HF10 \\
\hline COD & $77 \pm 10$ & $82 \pm 9$ \\
\hline BOD & $96 \pm 4$ & $96 \pm 5$ \\
\hline TSS & $92 \pm 7$ & $99 \pm 1$ \\
\hline Turbidity & $95 \pm 4$ & $99 \pm 1$ \\
\hline TN & $63 \pm 25$ & $53 \pm 26$ \\
\hline $\mathrm{NH}_{4}{ }^{-}-\mathrm{N}$ & $57 \pm 26$ & $61 \pm 29$ \\
\hline $\mathrm{TP}$ & $20 \pm 31$ & $37 \pm 25$ \\
\hline DRP & $18 \pm 55$ & $14 \pm 64$ \\
\hline E. coli & $99.7 \pm 0.6$ & $99.9 \pm 0.2$ \\
\hline Total coliforms & $99.6 \pm 0.6$ & $99.95 \pm 0.1$ \\
\hline
\end{tabular}

As can be observed, both treatment lines were very efficient at the removal of organic matter (BOD 5 and COD), turbidity and TSS. The average removals of (HF40: 63\%, HF10: 53\%) and $\mathrm{NH}_{4}{ }^{+}-\mathrm{N}$ (HF40: 57\%, HF10: 61\%) for all the experimental period fall in the upper limit of the range provided for CWs (40-60\%) by Vymazal [28]. Those of TP (20-37\%) and DRP (18-14\%) were clearly lower. However, the removals of $\mathrm{NH}_{4}{ }^{+}-\mathrm{N}$ and DRP were strongly affected by HLR, as will be discussed in the following section.

The effect of a design parameter on the performance of CWs is usually measured by comparing the obtained average removals [29], but the high dispersion of the data can obscure the results and lead to ambiguous conclusions [27]. Another way to compare the efficiencies of HF40 and HF10 is to determine their capability to meet the legislation by measuring the percentage of samples with concentrations below the legal limits. Table 4 shows the degree of compliance with the Spanish National Regulation as the percentage of samples with values below those established by the Royal Decrees that regulate the limits for: (i) COD regarding the discharge of treated wastewater into the environment [30] and (ii) TSS, turbidity and E. coli, considering the possible reuse (urban, agricultural, industrial, recreational and environmental) of treated wastewater [31].

Table 4. Degree of compliance with the Spanish National Regulation measured as percentage of samples (\%) with values below the legal limits for discharging treated wastewater into the environment [30] and re-use [31]. Units of Chemical Oxygen Demand (COD), TSS, turbidity and E. coli are mg COD/L, $\mathrm{mg} / \mathrm{L}, \mathrm{NTU}$ and CFU/100 mL, respectively.

\begin{tabular}{ccccc}
\hline & HF40 (\%) & HF10 (\%) & Legal Limit & Legal Regulation \\
\hline COD & 73 & 90 & 125 & R.D. 509/1996 \\
\hline TSS & 54 & 100 & 10 & \\
\hline \multirow{2}{*}{ Turbidity } & 25 & 61 & 2 & \multirow{2}{*}{ R.D. 1620/2007 } \\
& 83 & 100 & 10 & \\
\hline \multirow{2}{*}{ E. coli } & 33 & 33 & 102 & R.D. 1620/2007 \\
& 40 & 53 & 103 & \\
\hline
\end{tabular}


As can be seen, the degree of compliance of HF10 was higher than that of HF40 for COD $(90 \%$ vs. $73 \%$ ), TSS ( $54 \%$ vs. $100 \%$ ), turbidity ( 2 NTU: $61 \%$ vs. $25 \%, 10$ NTU: $100 \%$ vs. $83 \%$ ).

\subsubsection{Effect of HLR}

To determine the effect of SLR on the efficiency of the HF CWs, the influent pump working time was doubled on 30 March 2016. Thus, two different periods can be regarded. Table 3 summarizes the SLRs of HF10 and HF40 for the periods of high and low SLRs.

As can be observed in Table 5, the SLRs of both treatment lines were quite similar $(p>0.05)$ for each period and the removals can be compared. Figure 2 illustrates the removals of $\mathrm{COD}, \mathrm{NH}_{4}{ }^{+}-\mathrm{N}$, DRP, turbidity, E. coli and total coliforms in HF40 and HF10 and Table 6 summarizes the average SLRs and the removals achieved.

Table 5. Average surface loadings rates ( \pm standard deviation) of HF40 and HF10 in the periods of high and low loading rates.

\begin{tabular}{ccccc}
\hline & \multicolumn{2}{c}{ HF40 } & \multicolumn{2}{c}{ HF10 } \\
\cline { 2 - 5 } & Low & High & Low & High \\
\hline HLR, $\mathrm{L} / \mathrm{m}^{2} \mathrm{~d}$ & $25 \pm 5$ & $51 \pm 8$ & $26 \pm 4$ & $51 \pm 7$ \\
COD-LR, g/m $\mathrm{m}^{2} \mathrm{~d}$ & $12 \pm 5$ & $24 \pm 10$ & $12 \pm 5$ & $25 \pm 11$ \\
TSS-LR, g/m $/ \mathrm{m}^{2} \mathrm{~d}$ & $4 \pm 2$ & $6.5 \pm 4$ & $5 \pm 3$ & $7 \pm 4$ \\
\hline
\end{tabular}

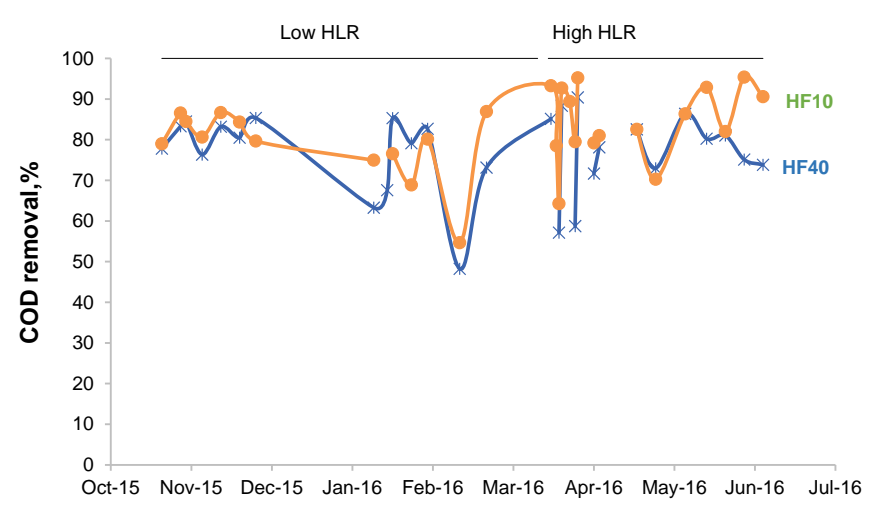

(a)

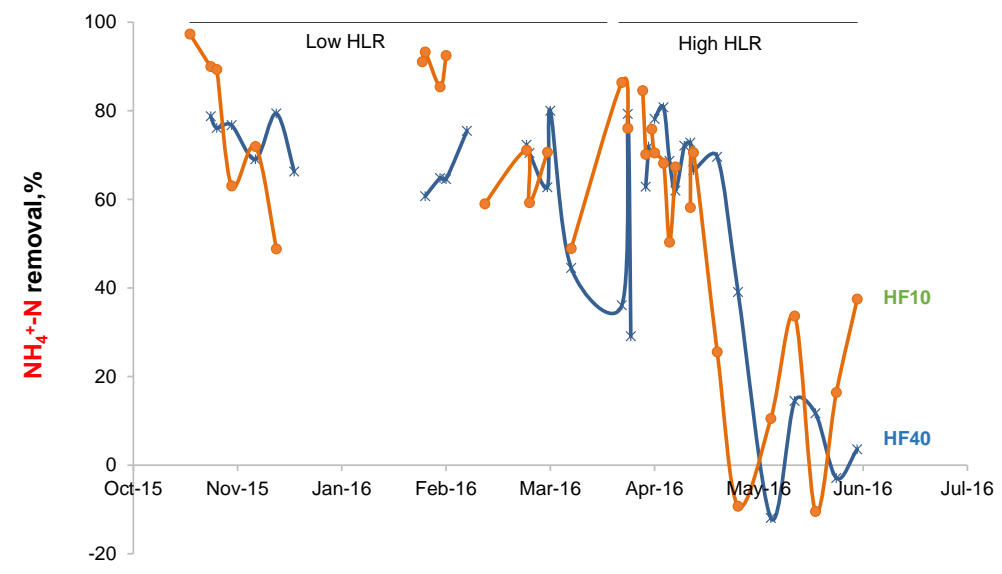

(b)

Figure 2. Cont. 


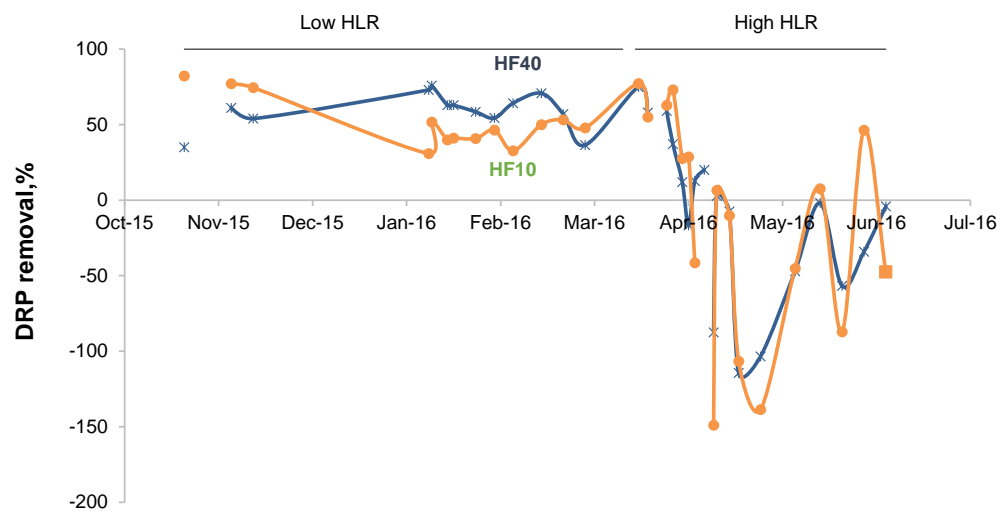

(c)
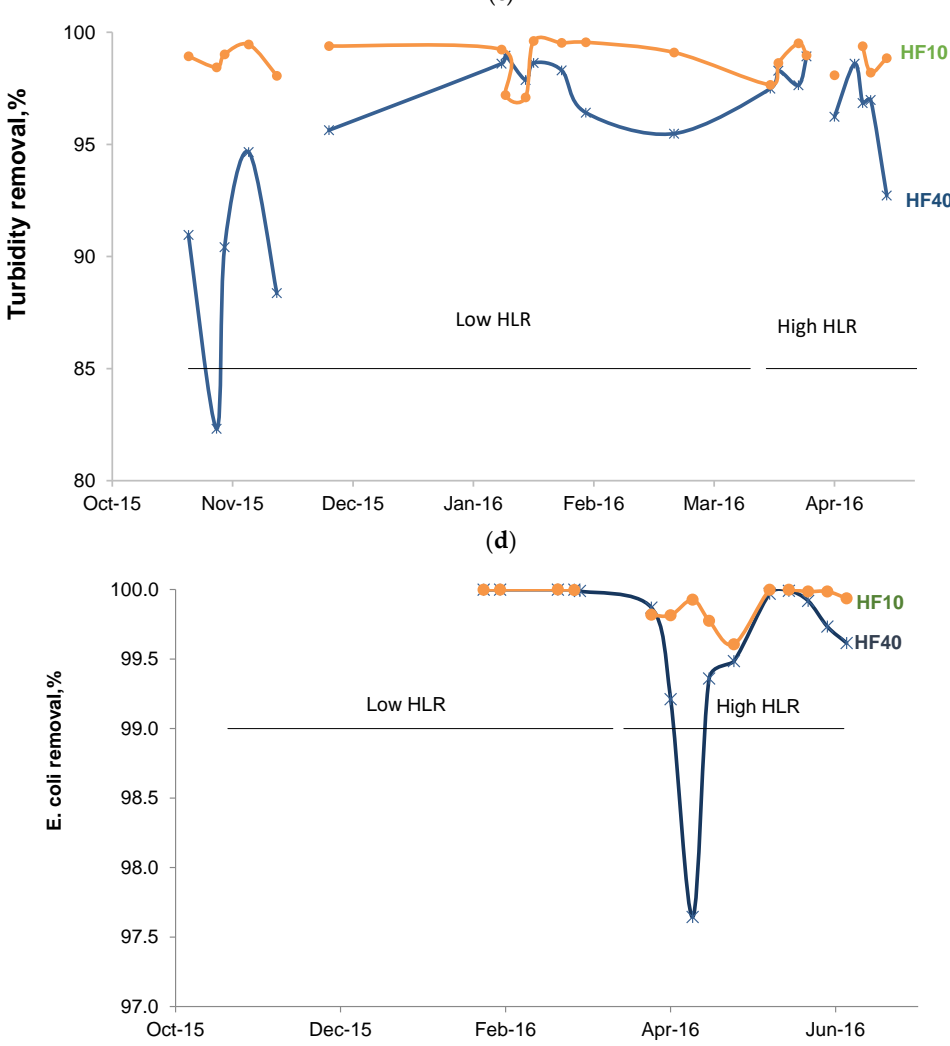

(e)

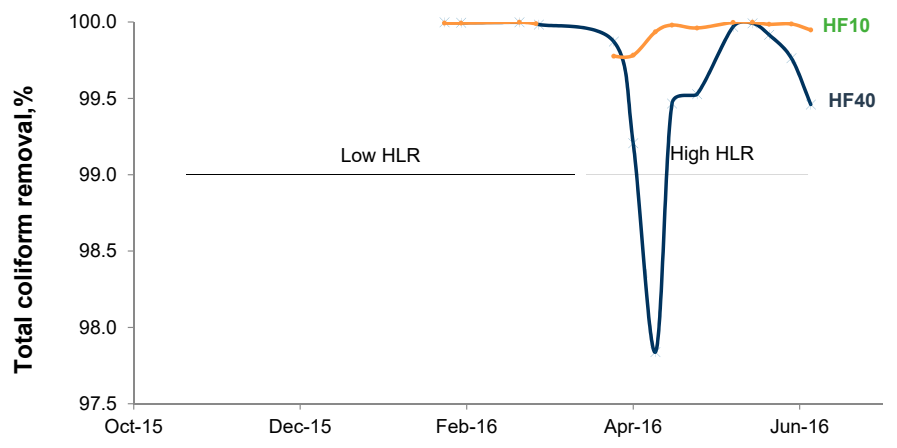

(f)

Figure 2. Removal (\%) of: (a) COD, (b) $\mathrm{NH}_{4}{ }^{+}-\mathrm{N}$, (c) DRP, (d) turbidity, (e) E. coli and (f) total coliforms in HF40 and HF10 during the periods of high and low HLR. 
Table 6. Average removals (\%, \pm standard deviation) for HF40 and HF10 in the periods of low and high hydraulic loading rate (HLR). The different letters next to the same raw values denote significant differences for the considered parameter.

\begin{tabular}{ccccc}
\hline & \multicolumn{2}{c}{ HF40 } & \multicolumn{2}{c}{ HF10 } \\
\cline { 2 - 5 } & Low HLR & High HLR & Low HLR & High HLR \\
\hline COD & $76 \pm 11$ & $78 \pm 11$ & $79 \pm 9$ & $85 \pm 9$ \\
$\mathrm{NH}_{4}{ }^{+}-\mathrm{N}$ & $67 \pm 12$ & $48 \pm 31$ & $75 \pm 10$ & $49 \pm 31$ \\
DRP & $60 \pm 13$ & $-16 \pm 52$ & $53 \pm 17$ & $-20 \pm 61$ \\
Turbidity & $94 \pm 5^{\mathrm{a}}$ & $97 \pm 2^{\mathrm{b}}$ & $99 \pm 1^{\mathrm{b}}$ & $99 \pm 1^{\mathrm{b}}$ \\
E. coli & $99.997 \pm 0.004^{\mathrm{a}}$ & $99.5 \pm 0.7^{\mathrm{b}}$ & $99.998 \pm 0.1^{\mathrm{a}}$ & $99.9 \pm 0.1^{\mathrm{b}}$ \\
Total coliforms & $99.994 \pm 0.01^{\mathrm{a}}$ & $99.5 \pm 0.6^{\mathrm{b}}$ & $99.994 \pm 0.0^{\mathrm{a}}$ & $99.9 \pm 0.08^{\mathrm{b}}$ \\
\hline
\end{tabular}

The results from Figure 2 and Table 6 indicate that augmenting the SLR reduced the removals of $\mathrm{NH}_{4}{ }^{+}-\mathrm{N}$, DRP and fecal indicators but those of COD and turbidity remained high. Figure 3 shows the mass removal rates $\left(\mathrm{g} / \mathrm{m}^{2} \mathrm{~d}\right.$ ) of COD, $\mathrm{NH}_{4}{ }^{+}-\mathrm{N}$ and DRP and E. coli in the first stages (HF40-and HF10-1) and second stages of the HF CWs (HF40-2 and HF10-2) during the periods of high and low HLR. In the case of COD, the first stages achieved the highest COD mass removal rates in both periods.

In the period of low HLR, the average removals of $\mathrm{NH}_{4}{ }^{+}-\mathrm{N}$ were high for HF CWs (HF40: $67 \%$, HF10: 75\%, Table 6), suggesting the availability of enough dissolved oxygen to support nitrification. This could be partially due to the fact that the first unit of the CWs was placed above the other ones and the influent was intermittently dosed. Thus, a fill and drain effect was obtained that would favor the aeration of the substrate. Unfortunately, the role of the plants in terms of $\mathrm{N}$ removal was not considered in this study. When the HLR was increased, the removal of $\mathrm{NH}_{4}{ }^{+}-\mathrm{N}$ decreased (HF40: 48\%, HF10: 49\%) and became more unstable, as shown by the higher standard deviations observed (Table 6 and Figure 3). Unlike the results of this study, Nivala et al. [27] found negligible $\mathrm{NH}_{4}{ }^{+}-\mathrm{N}$ removal in shallow $\mathrm{HFCWs}$, though the shallowest systems achieved the lowest mean effluent $\mathrm{NH}_{4}{ }^{+}-\mathrm{N}$ concentrations. In this study, in the low HLR period, similar surface removal rates were observed in both parts of the HFs. However, when the HLR increased, the surface removal rates also increased in both stages, being slightly better in the first stage, as observed for COD (Figure 2).

The average DRP removals in the period of low HLR were statistically similar (HF40: 60\%, HF10: $53 \%, p>0.05$ ) and were high for HF CWs. Nonetheless, the high HLR had a notoriously negative effect, since DRP removals became negative (HF40: $-16 \%$, HF10: $-20 \%$ ). Dierberg et al. [32] found that TP retention efficiency decreased at high HLR due to lower HRT, as it favored preferential flow and affected the P diffusion and sorption processes. It is widely accepted that the main DRP removal mechanism in CWs is the adsorption/precipitation on the substrate, as plant uptake and microbial activity are less important [33]. It was expected that the sand used in the final unit of HF10 and HF40, with a high carbonate content, and thus in $\mathrm{Ca}^{2+}$ and $\mathrm{Mg}^{2+}$ ions, could help in the removal of DRP by precipitation [34]. However, the porous media used in these experiments (palm mulch, gravel and sand) did not have any removal phosphorus removal capacity, as observed in lab experiments. This can explain why there was no difference in the DRP surface removal rate removal in both stages of HF10 and HF40 (Figure 3). Thus, the results of this study indicate that plant uptake and microbial activity had a more relevant role than expected. In fact, plant uptake is considered to be the second most important mechanism of P removal [35]. Additionally, microbial P removal by means of polyphosphate-accumulating organisms can be an important mechanism [36]. These authors found that an intermediate HRT provided the best removal of TP in VFs, as it provided a balance between $P$ adsorption on the substrate and release under anaerobic conditions. This effect can explain the negative DRP removals observed in the high HLR period of the present study. 


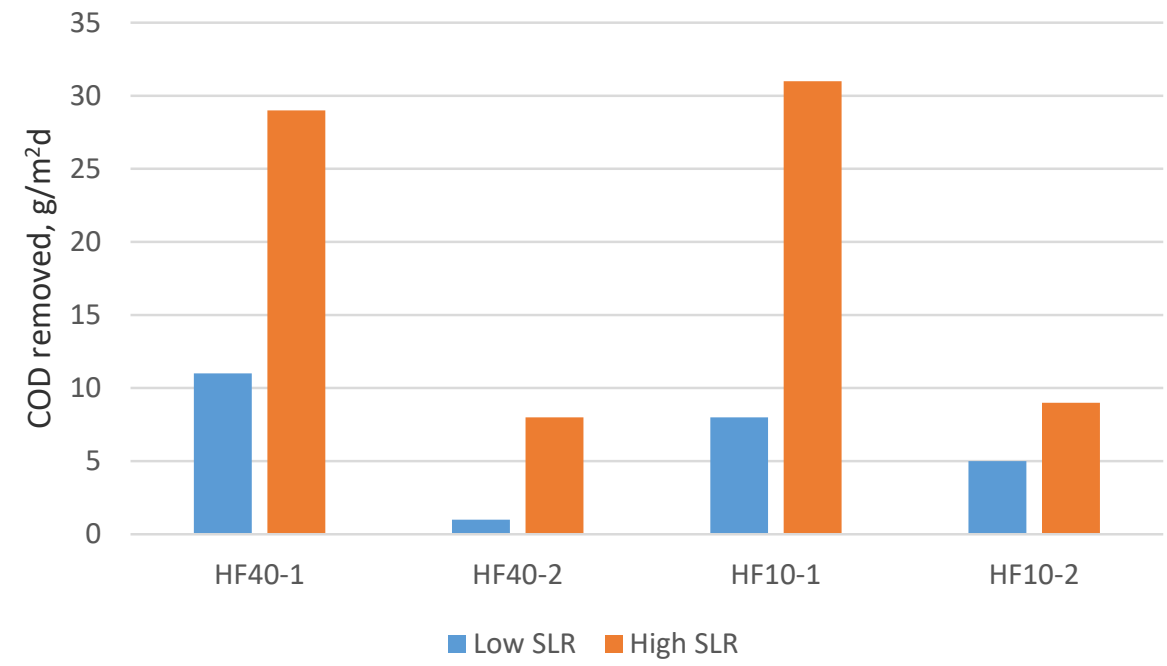

3
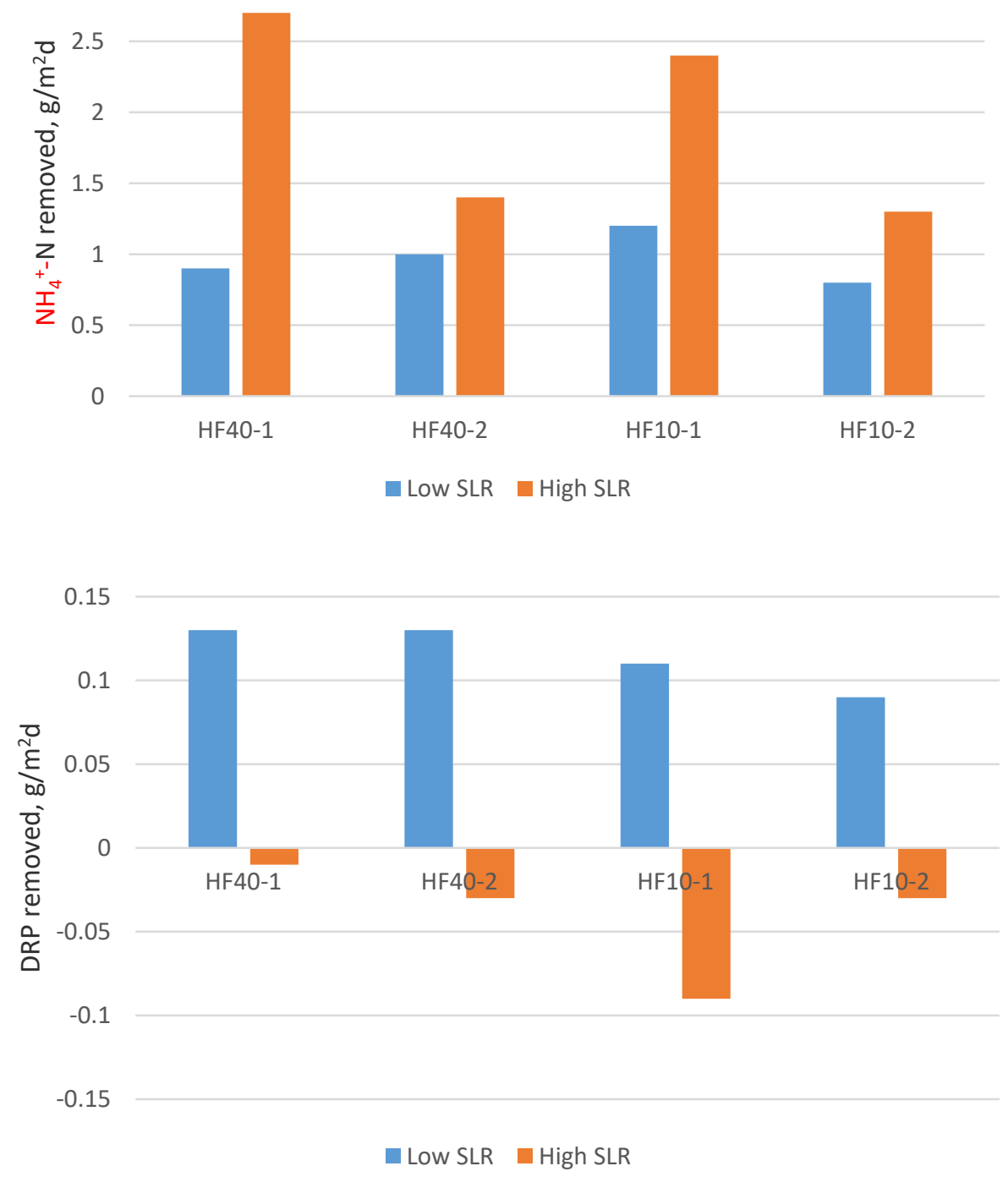

Figure 3. Cont. 


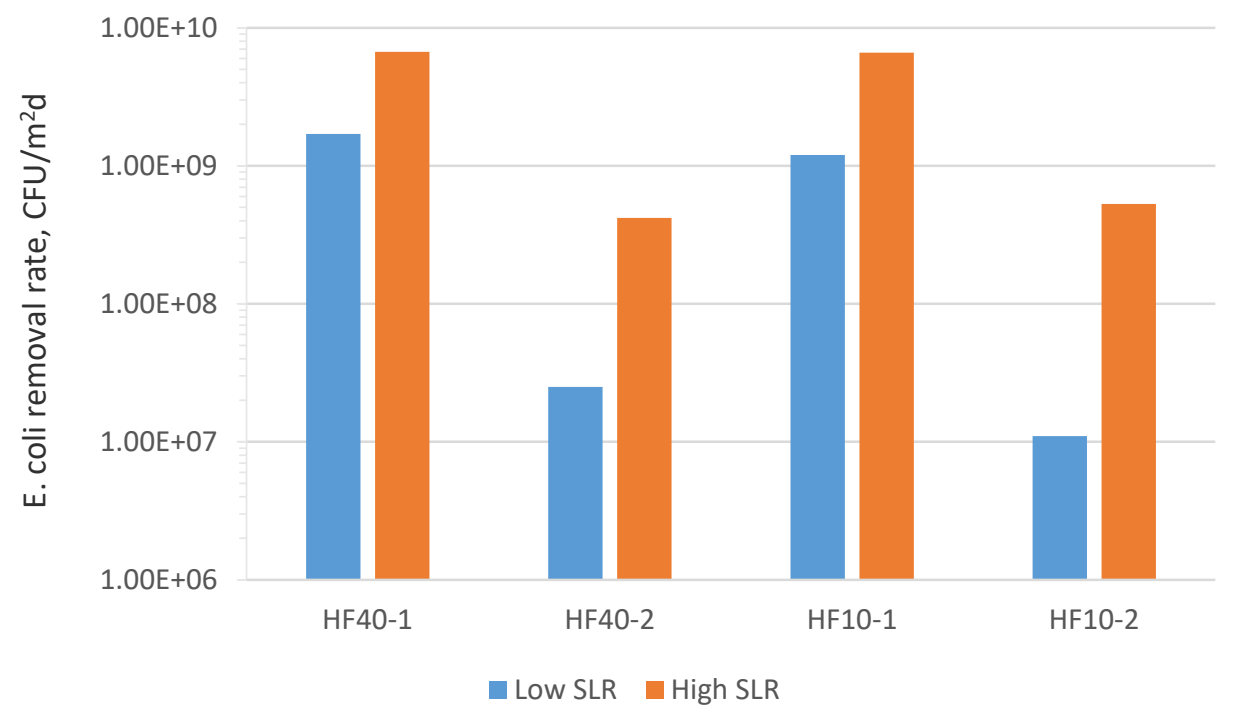

Figure 3. Average surface loading removal rates $\left(\mathrm{g} / \mathrm{m}^{2} \mathrm{~d}\right)$ of $\mathrm{COD}, \mathrm{NH}_{4}{ }^{+}-\mathrm{N}, \mathrm{DRP}$, and E. coli $\left(\mathrm{CFU} / \mathrm{m}^{2} \mathrm{~d}\right)$ in the first stage (HF40-1 and HF10-1) and second stage (HF40-2 and HF10-2) of the HF CWs for the periods of low and high SLR.

The main mechanisms of pathogen removal in CWs are to kill them off by starvation or predation, sedimentation, filtration and adsorption [37]. Many different variables play a role in the removal of pathogens in CWs: temperature, influent composition, HRT and HLR, water flow type (surface, sub-surface, vertical or horizontal), the presence and type of macrophytes or the substrate [38]. Additionally, Morató et al. [23] observed that water depth had also an important effect on disinfection. The results from the present study do not reveal a significant role of water depth regarding E. coli and total coliform elimination (Table 6). During the low SLR period, E. coli and total coliform removals of almost five orders of magnitude were registered for both treatment lines (Table 6). Other authors have found similar E. coli and pathogen removals in CWs using fine soil [39] and sand [40] as substrates, but such high removals are not usually found in CWs [38].

In the case of $E$. coli and total coliforms, a clear removal reduction was observed after increasing the HLR for HF40 with respect to HF10 (Figure 2). This fact suggests the higher robustness of the latter. The analysis of surface removal rates for the first and second stages of HF40 and HF 10 (Figure 3) reveals a similar behavior of that of COD: a higher average SLR removal of both parameters at higher SLR and a stronger retention in the first part of the system (H40-1 and HF10-1). The results of this study suggest that the presence of the sand in the last treatment units of HF10 and HF40 did not play a key role in the removal of pathogens, since SLR removals were not better in the second stages of the treatment lines. This fact suggests that the presence of the plants and the good aeration of the substrate (as shown by the good $\mathrm{NH}_{4}{ }^{+}-\mathrm{N}$ removals observed) are the main pathogen removal mechanisms. Macrophytes can improve pathogen removal by increasing HRT with their root system [41] and providing a larger surface area for microbe attachment, favoring the formation of biofilms, oxygen seepage through roots, the secretion of plant exudates, etc. [38].

\subsubsection{Hybrid CWs: Sand vs. Mulch Substrates for the VF Stage}

The hybrid CWs achieved similar average removals without significant differences, as can be seen in Table 7. However, the preliminary results of the first 3 months of operation of Hybrid CW 1 with sand, were especially good and better than those of Hybrid CW 2, with removals of $\mathrm{NH}_{4}{ }^{+}-\mathrm{N}$ and E. coli greater than $90 \%$ and $4-5 \log$ units, respectively. The E. coli concentrations in the effluent were $40-540 \mathrm{CFU} / 100 \mathrm{~mL}$, although HLRs as high as $426 \mathrm{~L} / \mathrm{m} 2 \mathrm{~d}$ were used in the VF stage (Table 2). However, after about 3 months of operation, the first symptoms of clogging began to be observed, i.e., ponding on the surface of the sand-based VF. In consequence, performance was dramatically 
reduced. Initially, maintenance strategies such as resting periods of several days and scraping the surface were enough to unclog the filter, but after about 9 months of operation it became irreversibly clogged. It was necessary to remove a $0.10 \mathrm{~m}$ layer on its surface to recover an acceptable hydraulic conductivity, but the initial high performances were not observed again. Clogging is the main cause of malfunction in vertical sand filters and is the cause of the oxygen transfer reduction in vertical flow filters [42]. This can explain the obtained results, since nitrification is very sensitive to oxygenation and E. coli removal is faster in aerobic conditions. The results of the present study partially agree with those of de Oliveira Cruz [43] who found clogging problems after only 4 months of operation in a sand filter. However, the full restoration of its function was recovered by scraping off a shallow layer on its surface.

Table 7. Average removal (\%) ( \pm standard deviation) of Hybrid CW 1 (HF: mulch, VF: sand) and Hybrid CW 2 (HF: mulch, VF: mulch).

\begin{tabular}{ccc}
\hline & Hybrid CW 1 & Hybrid CW 2 \\
\hline COD & $73 \pm 18$ & $79 \pm 10$ \\
\hline BOD & $96 \pm 4$ & $96 \pm 4$ \\
\hline TSS & $98 \pm 1$ & $96 \pm 5$ \\
\hline Turbidity & $98 \pm 1$ & $98 \pm 2$ \\
\hline $\mathrm{TN}$ & $43 \pm 28$ & $55 \pm 20$ \\
\hline $\mathrm{NH}_{4}{ }^{+} \mathrm{N}$ & $52 \pm 77$ & $64 \pm 28$ \\
\hline $\mathrm{TP}$ & $23 \pm 26$ & $24 \pm 32$ \\
\hline $\mathrm{DRP}$ & $9 \pm 36$ & $14 \pm 40$ \\
\hline E. coli & $99.0 \pm 1.5$ & $99.5 \pm 0.7$ \\
\hline Total coliforms & $99.0 \pm 2$ & $99.5 \pm 1$ \\
\hline
\end{tabular}

Nevertheless, Hybrid CW 2 (only mulch) remained unclogged throughout the whole experimental period. The only maintenance required was the addition of mulch because of the reduction in the height of the substrate, which occurred more rapidly at the beginning of the experimental period, falling by $20 \%$ in the first months. The substrate was added, and the subsequent reductions were minimal. Regarding clogging, woodchips were also preferred to sand as substrates for filters treating soiled dairy water [44].

\subsection{Comparison of the General Performance of the Multistage HF CWs and Hybrid CWs}

The selection of a treatment system is made based on its efficiency, but also by taking into account the economic cost and ease of construction and maintenance. Table 8 shows the concentrations of the different parameters analyzed in the effluent of the hybrid and multistage HF CWs. In the case of the latter, only those of the higher SRL period were included, with the goal of comparing results with similar SLRs. As can be observed, the effluent concentrations of HF10 are lower than those of the other systems for BOD, COD, TSS, turbidity, E. coli and total coliforms, but not significantly. On the other hand, the construction and maintenance of a HF CW is easier than that of a hybrid CW. Thus, the recommended system for the treatment of raw urban wastewater without clogging problems would be HF10. 
Table 8. Concentrations in the effluents of the CWs studied.

\begin{tabular}{ccccc}
\hline & Hybrid CW 1 & Hybrid CW 2 & HF40 & HF10 \\
\hline COD & $120 \pm 82$ & $102 \pm 48$ & $110 \pm 47$ & $93 \pm 53$ \\
BOD & $11 \pm 11$ & $12 \pm 15$ & $10 \pm 13$ & $9 \pm 2$ \\
TSS & $6 \pm 6$ & $7 \pm 9$ & $6 \pm 5$ & $2 \pm 1$ \\
Turbidity & $2 \pm 1$ & $3 \pm 2$ & $8 \pm 8$ & $2 \pm 1$ \\
TN & $37 \pm 14$ & $28 \pm 9$ & $28 \pm 15$ & $30 \pm 14$ \\
$\mathrm{NH}_{4}{ }^{-}-\mathrm{N}$ & $20 \pm 15$ & $25 \pm 17$ & $24 \pm 14$ & $23 \pm 12$ \\
TP & $8 \pm 4$ & $9 \pm 5$ & $9 \pm 5$ & $8 \pm 5$ \\
DRP & $7 \pm 3$ & $7 \pm 3$ & $8 \pm 4$ & $8 \pm 4$ \\
E. coli & $2.9( \pm 4.3) \times 10^{4}$ & $1.8( \pm 2.4) \times 10^{4}$ & $2.4( \pm 5.8) \times 10^{4}$ & $9.1( \pm 1.8) \times 10^{3}$ \\
Total coliforms & $2.7( \pm 4.9) \times 10^{4}$ & $1.3( \pm 1.3) \times 10^{4}$ & $3.4( \pm 6.5) \times 10^{4}$ & $3.8( \pm 4.8) \times 10^{3}$ \\
\hline
\end{tabular}

\section{Conclusions}

CWs are regarded as a sustainable wastewater treatment technology. However, the extraction and transport of gravel and sand used to build CWs have a non-negligible environmental impact that can be reduced by using residual materials such as agro-forest wastes. To improve our knowledge on the use of this alternative material, pilot scale multistage HF CWs and hybrid CWs, in which gravel and sand have been partially or totally replaced by palm mulch, have been compared.

In the multistage HF CWs, the effect of water level height and HLR was studied. The best results were obtained with the shallowest system and an SLR of $12 \mathrm{~g} \mathrm{COD} / \mathrm{m}^{2} \mathrm{~d}$. Using sand in the VF stage of the hybrid CW provided remarkably good $\mathrm{NH}_{4}{ }^{+}-\mathrm{N}$ and E. coli removals, but only during the first months of operation. Then, clogging problems considerably reduced the performance, which was initially similar to that of the mulch-based hybrid CW, which, on the other hand, did not clog.

Considering the removals obtained and the fact that there were no clogging incidents in this study, in addition to the easier construction and operation of HF CWs, a mulch-based multistage HF CW would be a better option than a mulch-based hybrid CW for the economic and sustainable treatment of raw urban wastewater in small communities.

Author Contributions: The idea for this article was developed by J.A.H.-M. Sampling and analyses were performed by M.M.-A. The paper was written by J.A.H.-M., R.G.-A., P.G.-J., M.C.-A. and E.R. All authors have read and agree to the published version of the manuscript.

Funding: This research was partially funded by the Departments of Chemistry and Biology of the University of Las Palmas de Gran Canaria (Spain).

Acknowledgments: The authors acknowledge the financial and technical support of the University of Las Palmas de Gran Canaria (Spain).

Conflicts of Interest: The authors declare no conflict of interest.

\section{References}

1. Molinos-Senante, M.; Gómez, T.; Caballero, R.; Hernández-Sancho, F.; Sala-Garrido, R. Assessment of wastewater treatment alternatives for small communities: An analytic network process approach. Sci. Total Environ. 2015, 532, 676-687. [CrossRef] [PubMed]

2. Vymazal, J. Is removal of organics and suspended solids in horizontal sub-surface flow constructed wetlands sustainable for twenty and more years? Chem. Eng. J. 2019, 378, 122117. [CrossRef]

3. Schandl, H. Global Material Flows and Resource Productivity. In An Assessment Study of the UNEP International Resource Panel; U.N. Environment Programme: Paris, France, 2016; pp. 30-34.

4. Torres, A.; Brandt, J.; Lear, K.; Liu, J. A looming tragedy of the sand commons. Science 2017, 357, $970-971$. [CrossRef] [PubMed]

5. Bendixen, M.; Best, J.; Hackney, C.; Iversen, L.L. Time is running out for sand. Nature 2019, 571, $29-31$. [CrossRef] [PubMed]

6. Vohla, C.; Kõiv, M.; Bavor, H.J.; Chazarenc, F.; Mander, Ü. Filter materials for phosphorus removal from wastewater in treatment wetlands-A review. Ecol. Eng. 2011, 37, 70-89. [CrossRef] 
7. Saeed, T.; Muntaha, S.; Rashid, M.; Sun, G.; Hasnat, A. Industrial wastewater treatment in constructed wetlands packed with construction materials and agricultural by-product. J. Clean. Prod. 2018, 189, 442-453. [CrossRef]

8. Wang, R.; Korboulewsky, N.; Prudent, P.; Domeizel, M.; Rolando, C.; Bonin, G. Feasibility of using an organic substrate in a wetland system treating sewage sludge: Impact of plant species. Bioresur. Technol. 2010, 101, 51-57. [CrossRef]

9. Saeed, T.; Sun, G. Enhanced denitrification and organics removal in hybrid wetland columns: Comparative experiments. Bioresour. Technol. 2011, 102, 967-974. [CrossRef]

10. Tee, H.C.; Lim, P.E.; Seng, C.E.; Nawi, M.A.M. Newly developed baffled subsurface-flow constructed wetland for the enhancement of nitrogen removal. Bioresour. Technol. 2012, 104, 235-242. [CrossRef]

11. Saeed, T.; Sun, G. A lab-scale study of constructed wetlands with sugarcane bagasse and sand media for the treatment of textile wastewater. Bioresour. Technol. 2013, 128, 438-447. [CrossRef]

12. Wu, H.; Zhang, J.; Ngo, H.H.; Guo, W.; Hu, Z.; Liang, S.; Liu, H. A review on the sustainability of constructed wetlands for wastewater treatment: Design and operation. Bioresour. Technol. 2015, 175, 594-601. [CrossRef] [PubMed]

13. Herrera-Melián, J.A.; Guedes-Alonso, R.; Borreguero-Fabelo, A.; Santana-Rodríguez, J.J.; Sosa-Ferrera, Z. Study on the removal of hormones from domestic wastewaters with lab-scale constructed wetlands with different substrates and flow directions. Environ. Sci. Pollut. Res. 2018, 25, 20374-20384. [CrossRef] [PubMed]

14. Rambags, F.; Tanner, C.C.; Stott, R.; Schipper, L.A. Bacteria and virus removal in denitrifying bioreactors: Effects of media type and age. Ecol. Eng. 2019, 138, 46-53. [CrossRef]

15. García, J.; Aguirre, P.; Barragán, J.; Mujeriego, R.; Matamoros, V.; Bayona, J.M. Effect of key design parameters on the efficiency of horizontal subsurface flow constructed wetlands. Ecol. Eng. 2005, 25, 405-418. [CrossRef]

16. Sánchez-Ramos, D.; Agulló, N.; Samsó, R.; García, J. Effect of key design parameters on bacteria community and effluent pollutant concentrations in constructed wetlands using mathematical models. Sci. Total Environ. 2017, 584, 374-380. [CrossRef]

17. Song, H.L.; Nakano, K.; Taniguchi, T.; Nomura, M.; Nishimura, O. Estrogen removal from treated municipal effluent in small-scale constructed wetland with different depth. Bioresour. Technol. 2009, 100, 2945-2951. [CrossRef]

18. Vo, T.; Bui, X.; Lin, C.; Nguyen, V.; Hoang, T.; Nguyen, H.; Nguyen, P.; Ngo, H.H.; Guo, W. A mini-review on shallow-bed constructed wetlands: A promising innovative green roof. Curr. Opin. Environ. Sci. Health 2019, 12, 38-47. [CrossRef]

19. Holland, J.; Martina, J.F.; Granata, T.; Bouchard, V.; Quigley, M.; Brown, L. Effects of wetland depth and flow rate on residence time distribution characteristics. Ecol. Eng. 2004, 23, 189-203. [CrossRef]

20. Nivala, J.; Knowles, P.; Dotro, G.; García, J.; Wallace, S. Clogging in subsurface-flow treatment wetlands: Measurement, modeling and management. Water Res. 2012, 46, 1621-1640. [CrossRef]

21. Knowles, P.; Dotro, G.; Nivala, J.; García, J. Clogging in subsurface-flow treatment wetlands: Occurrence and contributing factors. Ecol. Eng. 2011, 37, 99-112. [CrossRef]

22. Herrera-Melián, J.A.; Torres-Padrón, M.E.; Betancor-Abreu, A.; Sosa-Ferrera, Z.; Santana-Rodríguez, J.J.; Martín-González, M.A.; Araña, J.; Guedes-Alonso, R. Clogging reduction and removal of hormone residues with laboratory-scale vertical flow organic-based filter and hybrid wetland. Int. J. Environ. Sci. Technol. 2015, 12, 1039-1052. [CrossRef]

23. Morató, J.; Codony, F.; Sánchez, O.; Pérez, L.M.; García, J.; Mas, J. Key design factors affecting microbial community composition and pathogenic organism removal in horizontal subsurface flow constructed wetlands. Sci. Total Environ. 2014, 481, 81-89. [CrossRef]

24. American Public Health Association (APHA). Standard Methods for the Examination of Water and Wastewater, 21st ed.; American Public Health Association: Washington, DC, USA, 2005.

25. Metcalf, E.; Eddy, E. Wastewater Engineering: Treatment and Reuse; McGrawHill Inc.: New York, NY, USA, 2003.

26. Öövel, M.; Tooming, A.; Mauring, T.; Mander, Ü. Schoolhouse wastewater purification in a LWA-filled hybrid constructed wetland in Estonia. Ecol. Eng. 2007, 29, 17-26. [CrossRef]

27. Nivala, J.; Boog, J.; Headley, T.; Aubron, T.; Wallace, S.; Brix, H.; Mothes, S.; Afferden, M.; Müller, R.A. Side-by-side comparison of 15 pilot-scale conventional and intensified subsurface flow wetlands for treatment of domestic wastewater. Sci. Total Environ. 2019, 658, 1500-1513. [CrossRef] [PubMed] 
28. Vymazal, J. Removal of nutrients in various types of constructed wetlands. Sci. Total Environ. 2007, 380, 48-65. [CrossRef]

29. Ilyas, H.; Masih, I. The performance of the intensified constructed wetlands for organic matter and nitrogen removal: A review. J. Environ. Manag. 2017, 198, 372-383. [CrossRef]

30. Royal, D. 1620/2007, That Establishes the Legal Framework for the Reuse of Recovered Wastewater. Available online: http://www.boe.es/boe/dias/2007/12/08/pdfs/A50639-50661.pdf (accessed on 6 January 2020).

31. Royal, D. 509/1996, That Establishes the Norms Applicable to the Treatment of Urban Wastewaters. Available online: https://www.boe.es/diario_boe/txt.php?id=BOE-A-1996-7159 (accessed on 6 January 2020).

32. Dierberg, F.E.; Juston, J.J.; DeBusk, T.A.; Pietro, K.; Gu, B. Relationship between hydraulic efficiency and phosphorus removal in a submerged aquatic vegetation-dominated treatment wetland. Ecol. Eng. 2005, 25, 9-23. [CrossRef]

33. Babatunde, A.O.; Zhao, Y.Q.; Burke, A.M.; Morris, M.A.; Hanrahan, J.P. Characterization of aluminium-based water treatment residual for potential phosphorus removal in engineered wetlands. Environ. Pollut. 2009, 157, 2830-2836. [CrossRef]

34. Lan, W.; Zhang, J.; Hu, Z.; Ji, M.; Zhang, X.; Zhang, J.; Li, F.; Yao, G. Phosphorus removal enhancement of magnesium modified constructed wetland microcosm and its mechanism study. Chem. Eng. J. 2018, 335, 209-214. [CrossRef]

35. Mesquita, M.C.; Albuquerque, A.; Amaral, L.; Nogueira, R. Seasonal variation of nutrient removal in a full-size horizontal constructed wetland. Energy Procedia 2017, 136, 225-232. [CrossRef]

36. Du, L.; Chen, Q.; Liu, P.; Zhang, X.; Wang, H.; Zhou, Q.; Xu, D.; Wu, Z. Phosphorus removal performance and biological dephosphorization process in treating reclaimed water by Integrated Vertical-flow Constructed Wetlands (IVCWs). Bioresour. Technol. 2017, 243, 204-211. [CrossRef] [PubMed]

37. Wu, S.; Carvalho, P.N.; Müller, J.A.; Manoj, V.R.; Dong, R. Sanitation in constructed wetlands: A review on the removal of human pathogens and fecal indicators. Sci. Total Environ. 2016, 541, 8-22. [CrossRef] [PubMed]

38. Shingare, R.; Thawale, P.R.; Raghunathan, K.; Mishra, A.; Kumar, S. Constructed wetland for wastewater reuse: Role and efficiency in removing enteric pathogens. J. Environ. Manag. 2019, 246, 441-461. [CrossRef] [PubMed]

39. Ushijima, K.; Ito, K.; Ito, R.; Funamizu, N. Greywater treatment by slanted soil system. Ecol. Eng. 2013, 50, 62-68. [CrossRef]

40. Shingare, R.P.; Nanekar, S.V.; Thawale, P.R.; Karthik, R.; Juwarkar, A.A. Comparative study on removal of enteric pathogens from domestic wastewater using Typha latifolia and Cyperus rotundus along with different substrates. Int. J. Phytoremediat. 2017, 19, 899-908. [CrossRef]

41. Ranieri, E.; Gikas, P.; Tchobanoglous, G. BTEX removal in pilot-scale horizontal subsurface flow constructed wetlands. Desalin. Water Treat. 2013, 51, 3032-3039. [CrossRef]

42. Petitjean, A.; Forquet, N.; Boutin, C. Oxygen profile and clogging in vertical flow sand filters for on-site wastewater treatment. J. Environ. Manag. 2016, 170, 15-20. [CrossRef]

43. de Oliveira Cruz, L.M.; Araujo Gomes, B.G.L.; Tonetti, A.L.; Salles Figueiredo, I.C. Using coconut husks in a full-scale decentralized wastewater treatment system: The influence of an anaerobic filter on maintenance and operational conditions of a sand filter. Ecol. Eng. 2019, 127, 454-459. [CrossRef]

44. Murnane, J.G.; Brennan, R.B.; Healy, M.G.; Fenton, O. Assessment of intermittently loaded woodchip and sand filters to treat dairy soiled water. Water Res. 2016, 103, 408-415. [CrossRef] [PubMed]

(C) 2020 by the authors. Licensee MDPI, Basel, Switzerland. This article is an open access article distributed under the terms and conditions of the Creative Commons Attribution (CC BY) license (http://creativecommons.org/licenses/by/4.0/). 